TARNOWSKIE STUDIA TEOLOGICZNE 35 (2016) NR 2, S. 51-72

http://dx.doi.org/10.15633/tst.2105

ks. Rafał Wierzchanowski ${ }^{1}$

UNIWERSYTET KARDYNAŁA STEFANA WYSZYŃSKIEGO W WARSZAWIE

\title{
Dobro potomstwa w kanonicznym prawie małżeńskim. Próba syntezy
}

Ustawodawca kościelny w kan. $1055 \$ 1$ kodeksu prawa kanonicznego [dalej: KPK] z 1983 roku stwierdza, że małżeństwo jest „przymierzem, przez które mężczyzna i kobieta tworzą ze sobą wspólnotę całego życia, skierowaną ze swej natury do dobra małżonków oraz do zrodzenia i wychowania potomstwa”.

To pierwsza definicja małżeństwa w prawie kanonicznym, na jaką zdobył się aktualny kodeks. Wynika z niej, że instytucja małżeństwa ukierunkowana jest na realizację dwóch celów: dobra potomstwa (bonum prolis) i dobra małżonków (bonum coniugum). Oczywiście tak ustawiona hierarchia dóbr małżeńskich jest efektem ostatniego soboru, który w sposób wyjątkowy dowartościował element personalny. Wcześniejsze unormowania upatrywały istotny przedmiot zgody małżeńskiej jedynie w dobru potomstwa, którego prawne rozumienie przechodziło $\mathrm{w}$ historii swoistą ewolucję. Często określa się ją w doktrynie jako przejście od ius in corpus do sese mutuo tradunt et accipiunt. Stąd zamiarem niniejszego opracowania będzie próba przedstawienia tego procesu w historii prawa kanonicznego, ze szczególnym uwzględnieniem obowiązujących unormowań. Podjęcie tego tematu wydaje się uzasadnione, zwłaszcza w kontekście coraz większej liczby spraw wnoszonych do sądów kościelnych o stwierdzenie nieważności małżeństwa, z tytułu wykluczenia, pozytywnym aktem woli, bonum prolis. Zazwyczaj objawia się to permanentnym stosowaniem środków antykoncepcyjnych i wczesnoporonnych, albo też zamiarem poczęcia dziecka metodą in vitro.

\footnotetext{
Rafał Wierzchanowski - prezbiter diecezji tarnowskiej, doktor nauk prawnych, magister licencjat teologii, oficjał Sądu Diecezjalnego w Tarnowie, autor kilku artykułów z kanonicznego prawa małżeńskiego i procesowego, członek zwyczajny Stowarzyszenia Kanonistów Polskich.
} 
Aby zrozumieć kanoniczną doktrynę dotyczącą małżeństwa i jego celów, trzeba najpierw odnieść się do jej źródeł, tzn. do prawa rzymskiego i przekazu biblijnego.

\section{Prawo rzymskie i Biblia}

W obszarze starożytnej kultury rzymskiej małżeństwo było uznanym przez prawo związkiem mężczyzny i kobiety, zawieranym na stałe w celu prowadzenia wspólnego życia ${ }^{2}$. Jeśli dobrze wczytamy się w zachowane definicje małżeństwa, pochodzące od Modestyna i Justyniana ${ }^{3}$, to wyraźnie zauważymy dowartościowanie elementu communio, i to tak w jej aspekcie ludzkim, jak i boskim ${ }^{4}$. W małżeństwie Rzymianie upatrywali naturalną przestrzeń dla zrodzenia i wychowania potomstwa ${ }^{5}$. Zresztą jednym $\mathrm{z}$ wielu wymogów iustum matrimonium była pubertas. Tylko dojrzały mężczyzna (masculus pubes) i zdolna do rodzenia kobieta (femina potens) mogli zawrzeć małżeństwo. W tym celu dokonywano oględzin ciała ${ }^{6}$. Jeżeli osoby okazywały się niedojrzałe do efektywnego współżycia, związku nie uznawano za małżeństwo, aż do ziszczenia się dojrzałości. Ponieważ w okresie klasycznym nie badano zdolności płciowej nupturientów, stąd do małżeństwa dopuszczano także impotentów. Sytuacja uległa zmianie w prawie justyniańskim, które zabraniało małżeństwa osobom niezdolnym do spłodzenia potomstwa, tj. impotentom (spadones) i kastratom (castrati). Podobnie rzecz miała się za czasów Augusta, gdy niezbyt przychylnie patrzono na małżeństwa osób starszych, które straciły już zdolność rozrodczą. Stąd mężczyzna powinien

2 Por. A. Dębiński, Rzymskie prawo prywatne. Kompendium, Warszawa 2003, s. 181; J. Misztal-Konecka, Bigamia w prawie rzymskim, Lublin 2011, s. 85.

3 Modestyn: „Nuptiae sunt coniunctio maris et feminae et consortium omnis vitae, et humani iuris communicatio”. Natomiast w Instytucjach Justyniana czytamy: „Nuptiae autem sive matrimonium est vice et mulieris coniunctio, individuam consuetudinem vitae continens” (cyt. za: A. Dębiński, Rzymskie prawo prywatne..., s. 181-182).

4 Por. S. Treggiari, Roman marriage. Iusti Coniuges from the time of Cicero to the time of Ulpian, Oxford 1993, s. 9-10.

5 Por. P. Bonfante, Istituzioni di diritto romano, Milano 1932, s. 173-174; G. Leszczyński, Pojęcie „bonum coniugum” w prawie małżeńskim Kościoła, „Śląskie Studia Historyczno-Teologiczne" 36 (2003) Z. 1, s. 102.

6 P. E. Corbett, The Roman law of marriage, Oxford 1930 (przedruk 1969), s. 51; P. Zubert, Przeszkoda wieku do zaręczyn i małżeństwa w prawie rzymskim, „Roczniki Teologiczno-Kanoniczne" 13 (1966) z. 5, s. 91-93. 
pozostawać w związku małżeńskim od 20 do 60 roku życia, a kobieta od 20 do 50 roku życia. Taki związek uważano za ważny, choć z punktu widzenia lex Iulia nie oznaczał wypełnienia obowiązku z niego wynikającego ${ }^{7}$. Jasne światło na to zagadnienie rzucają starożytne mowy pogrzebowe ku czci żon ${ }^{8}$. Trzeba dodać, że w kulturach starożytnych zarzut bezpłodności zawsze obarczał kobietę. Brak dzieci postrzegano jako nieszczęście niweczące nadzieję na przedłużenie rodu i zachowanie przez najbliższych rodzinnego majątku. Sami cesarze, jak na przykład Oktawian August, niejednokrotnie zachęcali obywateli do posiadania gromadki dzieci i nobilitowali tych, którzy efektywnie wypełniali zalecenia „polityki prorodzinnej”". Tym samym brak dziecka sprawiał ból. Co więcej, historia zna sytuacje, gdy cesarz anulował małżeństwo i testament kobiety, która zawarła małżeństwo bez możliwości posiadania dzieci. Według tradycji pierwszym Rzymianinem, który w roku 235 przed Chrystusem oddalił swą żonę z powodu jej domniemanej bezpłodności, był Spuriusz Karwiliusz Ruga. Wielu ówczesnych myślicieli wyrażało przekonanie, że kobieca sterilitas stanowi wystarczający powód do rozwiązania małżeństwa ${ }^{10}$. Za to kobieta płodna była pożądana nawet po rozwodzie, gdyż jawiła się jako gwarancja przedłużenia rodu ${ }^{11}$.

Prawo kanoniczne, jakkolwiek korzysta $\mathrm{z}$ dorobku prawa rzymskiego, to jednak swoje główne źródło upatruje w Piśmie Świętym. W historii Izraela - do której bezpośrednio nawiązuje nauka chrześcijańska - małżeństwo było odbiciem przymierza Boga Jahwe ze swoim ludem ${ }^{12}$. W tej unii

7 Por. J. Misztal-Konecka, Bigamia w prawie rzymskim, s. 94-95; B. Biondi, Il diritto romano cristiano, t. 3, Milano 1954, s. 93.

${ }^{8}$ Przykładem jest chociażby elegia autorstwa Propercjusza sławiąca Kornelię, zmarłą żonę Lucjusza Emiliusza Paulusa Lepidusa. Więcej na ten temat: Laudatio Turiae - funebris oratio uxori dedicata (Pochwała Turii - mowa pogrzebowa ku czci żony), wprowadzenie, przekład i komentarz M. Jońca, Poznań 2011, s. 130.

9 Por. Laudatio Turiae..., s. 131.

${ }^{10}$ Warto wszakże podkreślić, że w ściśle określonych okolicznościach możliwość rozwodu dopuszczały zarówno tzw. ustawy królewskie, jak i ustawa xiI tablic. Wyraźny ślad tego pradawnego przekonania odnajdujemy również w pismach żyjącego na przełomie III i IV wieku jurysty Hermogeniana. Por. A. Tarwacka, Rozwód Carviliusa Rugi. Czy naprawdę pierwszy? „Czasopismo Prawno-Historyczne” 51 (2002) z. 1, s. 301-308.

${ }^{11}$ Por. Laudatio Turiae..., s. 135.

${ }^{12}$ Por. W. Góralski, Kościelne prawo małżeńskie, Warszawa 20o6, s. 23; S. Szymik, Małżeństwo w Biblii, w: Encyklopedia katolicka, t. 11, kol. 1058-1063; K. Romaniuk, Małżeństwo i rodzina w Biblii, Katowice 1981. 
osobowej Stary Testament upatrywał wartości duchowe, takie jak: miłość, zgodę i wzajemną pomoc małżonków ${ }^{13}$. Nowy Testament ostatecznie precyzuje naukę o małżeństwie, stwierdzając, że jest ono nierozerwalną wspólnotą życia mężczyzny i kobiety ${ }^{14}$. Chrystus podnosi małżeństwo do godności sakramentu ${ }^{15}$. To wyjątkowa wspólnota miłości, której miarą jest miłość Boga do człowieka i Chrystusa do Kościoła ${ }^{16}$. W tej wspólnocie bardzo ważne miejsce zajmuje dziecko. Sam Jezus w swoim nauczaniu akcentuje wartość małżeństwa i rodziny. Zresztą przyszedł na świat w rodzinie ludzkiej: Maryi i Józefa. Był ich radością i centrum, wokół którego skupiało się całe ich życie ${ }^{17}$. Bez wątpienia dzieci zajmują w Biblii znaczące miejsce, nawet uprzywilejowane. Nie ma zbyt wielu słów, które by tak często występowały w Piśmie Świętym. Wystarczy powiedzieć, że słowa „dziecko, dzieci” są w nim obecne aż 484 razy. W odniesieniu do potomstwa najistotniejszy jest tekst Księgi Rodzaju 1, 28, w którym Bóg wzywa ludzi do zaludnienia i zagospodarowania ziemi: „Po czym Bóg im błogosławił, mówiąc do nich: «Bądźcie płodni i rozmnażajcie się, abyście zaludnili ziemię i uczynili ją sobie poddaną; abyście panowali nad rybami morskimi, nad ptactwem powietrznym i nad wszystkimi zwierzętami pełzającymi po ziemi»". Starożytni komentatorzy i sami Izraelici nie mieli wątpliwości, że dzieci (zwłaszcza płci męskiej) były przejawem Bożego błogosławieństwa, ale też jego warunkiem ${ }^{18}$.

${ }_{13}$ Por. Rdz 2, 18-24; Pnp 1 - 8; Oz 3, 1-3; Iz 54, 62; Jr 2 - 3, 31; por. także: J. Homerski, $̇ \dot{y}$ cie religijne wspólnoty matżeńskiej i rodzinnej $w$ świetle tekstów biblijnych, „Zeszyty Naukowe Katolickiego Uniwersytetu Lubelskiego" 23 (1980) z. 3, s. 63-72; L. Stachowiak, Biblijny obraz małżeństwa od Starego do Nowego Testamentu, „Zeszyty Naukowe Katolickiego Uniwersytetu Lubelskiego" 23 (1980) z. 3, s. 17-24.

${ }^{14}$ Por. Mt 19, 5-6; Ef 5, 21-25; Kol 3, 18-19; J. Gaudemet, Zasada nierozerwalności matżeństwa od początków chrześcijaństwa do XII wieku, „Prawo Kanoniczne” 21 (1978) nr 3-4, s. 117-118; H. Stawniak, Jedność i nierozerwalność małżeństwa, „Prawo Kanoniczne” 34 (1991) nr 1-2, s. 110-117.

${ }^{15}$ Por. E. Sztafrowski, Prawo kanoniczne w okresie odnowy soborowej. Podręcznik dla duchowieństwa, t. 2, Warszawa 1979, s. 188; kan. 1055 KPK z 1983 roku; W. Góralski, Wykluczenie nierozerwalności małżeństwa w świetle najnowszego orzecznictwa Roty Rzymskiej, „Ius Matrimoniale" 3 (1998), s. 89-9o.

${ }^{16}$ Por. W. Góralski, Ius matrimoniale. Ze studiów nad kościelnym prawem małżeńskim, t. 1, Lublin 1990, s. 15.

${ }_{17}$ Por. Łk 2, 1-7, 22-52; 8, 19-20; Mt 1, 18-25; 2, 13-15; J 19, 25-27.

${ }_{18}$ Por. L. Stachowiak, Błogosławieństwo w Starym Testamencie, w: Encyklopedia katolicka, pod red. F. Gryglewicza i in., t. 2, Lublin 1976, kol. 682-683; T. Zadykowicz, Potomstwo, w: Encyklopedia katolicka, red. E. Gigilewicz, t. 16, Lublin kol. 119-120; G. Hierzenberger, Dziecko, w: Praktyczny słownik biblijny, red. A. Grabner-Haidera, Warszawa 1994, s. 283. 
Posiadanie dużej liczby dzieci uznawane było za jedno z najkonkretniejszych potwierdzeń mnogości Bożych łask, spływających na rodzinę $e^{19}$. Ci, którzy nie mieli dziecka, okryci byli hańbą ${ }^{20}$. Często spotykamy opisy przeżywania tragedii przez rodziców, którzy $z$ różnych powodów, przez długie lata nie posiadali potomstwa. Było tak w przypadku Abrahama i Sary, Jakuba i Racheli, Elkana i Anny, Zachariasza i Elżbiety. Naturalnie z darem potomstwa łączył się obowiązek odpowiedniego wychowania dzieci. Szerokie wskazania na ten temat możemy znaleźć w Księdze Powtórzonego Prawa, Księdze Przysłów i w Księdze Syracydesa ${ }^{21}$. Widzimy zatem, że zgodnie $\mathrm{z}$ wolą Stwórcy miłość małżeńska winna być zawsze otwarta na nowe życie. Bóg, stwarzając człowieka na swój obraz, zaprosił go jednocześnie do uczestnictwa w dziele stwórczym i w ojcowskiej miłości ${ }^{22}$. Płodność małżeńska jest niczym niezasłużonym darem Bożym, ale również owocem i znakiem miłości męża i żony, żywym świadectwem ich całkowitego oddania się. Jest także nakazem przyjęcia poczętego dziecka, urodzenia go i wychowania ${ }^{23}$.

\section{Od ojców Kościoła do kodeksu z 1917 roku}

Analizując pisma niektórych autorów wczesnochrześcijańskich, jak chociażby Tertuliana i Grzegorza z Nyssy, można zauważyć, że w małżeńskich aktach współżycia seksualnego widzieli oni działanie złe i grzeszne, które domagało się jakiegokolwiek usprawiedliwienia ${ }^{24}$. Stąd małżeństwu nadawano znaczenie środka leczącego namiętności (remedium concupiscentiae) ${ }^{25}$.

19 Por. S. Jankowski, Biblijny sens płodności $i$ niepłodności, „Chrześcijanin w Świecie” 19 (1987) nr 3, s. 8-16; Ch. Thomassen, Rodzina, w: Praktyczny słownik biblijny, kol. 1145.

${ }^{20}$ Por. $1 \mathrm{Sm} \mathrm{1,} 6$.

${ }_{21}$ Por. Pwt 4, 9; Syr 3; 30, 1-13; Prz $10-13$.

${ }^{22}$ Por. Jan Paweł II, adhort. Familiaris consortio, 43, 50 i 55.

${ }_{23}$ Por. J. Krajczyński, Walor prawny relacji interpersonalnych $w$ matżeństwie, „Ius Matrimoniale" 7 (2002) nr 13, s. 43.

${ }^{24}$ Nie bez znaczenia na ukształtowanie się tejże nauki pozostawały rozpowszechnione w okresie patrystyki poglądy spirytualistyczne, deprecjonujące wszelką cielesność, a zatem w konsekwencji także stosunki płciowe małżonków. Przykładem są niektóre sekty chrześcijańskie, np. nowacjanie, pryscylianie i montaniści. Poglądy takie potępił synod w Bradze w 574 roku: „Jeśli ktoś potępia małżeństwa ludzkie i ze wstrętem odnosi się do rodzenia potomstwa, jak mówili Manichejczyk i Pryscylian, ten niech będzie wyklęty" (Breviarium fidei. Wybór doktrynalnych wypowiedzi Kościoła, red. I. Bokwa i in., Poznań 2007, s. 92).

${ }_{25}$ Por. L. Świto, „Exclusio boni prolis” jako tytuł nieważności małżeństwa, Olsztyn 2003, s. 12. 
W pierwszej księdze swojego dzieła Ad uxorem Tertualian pisze, że małżeństwo potrzebne było kiedyś do zaludnienia ziemi, którą człowiek otrzymał od Boga do zagospodarowania. Jednak na późniejszym etapie historii zbawienia, gdy ponowne przyjście Chrystusa staje się kwestią czasu, ten pierwszorzędny cel stracił na aktualności, a jedyną racją istnienia małżeństwa pozostała jego właściwość lecząca ludzkie pożądliwości ${ }^{26}$.

Na kanwie różnych poglądów szczególne miejsce zajmuje doktryna św. Augustyna. Z jednej strony skłaniał się on do twierdzenia, że w cielesnym współżyciu małżonków tkwi element moralnie niepożądany, będący skutkiem grzechu pierworodnego, z drugiej jednak dostrzegał wartość i dobroć instytucji małżeństwa ${ }^{27}$. Zatem to grzech pierworodny spowodował powstanie pożądliwości, której domieszka zawsze zawiera się w akcie małżonków. Nieuporządkowana pożądliwość jest czymś złym, ale sam akt małżeński in se nie jest grzeszny (choć splamiony przez pożądliwość), jeśli będzie zrekompensowany tzw. dobrami małżeńskimi: potomstwem (proles), wzajemną wiernością (fides) i nierozerwalnością (sacramentum). Człowiek wierzący, który godzi się na pożycie małżeńskie obciążone pożądliwością, otrzymuje jednocześnie rekompensatę w postaci tych trzech dóbr. Stanowią one o wartości małżeństwa, „dając jednocześnie moralne uprawnienie do pożycia cielesnego i uwalniają od zarzutu poddania się pożądliwości" ${ }^{28}$. Tak więc jest rzeczą niezbędną, by małżonkowie w ludzkim akcie współżycia cielesnego, nie tyle zmierzali do osiągnięcia rozkoszy zmysłowej, ile raczej stawiali sobie za cel dobra małżeńskie, a zwłaszcza bonum prolis. Wtedy to ich akt, realizowany in humano modo, dokonuje się bez grzechu, jest legalny, godny szacunku, a nawet jest obowiązkiem ${ }^{29}$. Zrodzenie potomstwa stanowiło

${ }^{26}$ Por. Tertulian, Ad uxorem, lib. 1, w: Tertulian, Opera omnia, accurante J. P. Migne, Parisiis 1844 (Patrologiae cursus completus. Series Latina [dalej: PL], 1), s. 1273-1288; św. Grzegorz z Nyssy, De virginitate, w: św. Grzegorz z Nyssy, Opera quae reperiri potuerunt omnia, accurante J. P. Migne, Parisiis 1863 (Patrologiae cursus completus. Series Graeca”, 46), s. 317-416.

${ }_{27}$ Por. św. Augustyn, De bono coniugali, w: św. Augustyn, Opera omnia, accurante J. P. Migne, Parisiis 1865, PL 34, s. 394; św. Augustyn, De Genesi contra Manichaeos, w: św. Augustyn, Opera omnia, accurante J. P. Migne, Parisiis 1865, PL 34, s. 204. Szeroko na ten temat piszą: D. Lindner, Der Usus natrimonii. Untersuchung über seine sittliche Bewertung in der katholischen Moraltheologie alter und neuer Zeit, München 1929; A. Perego, Fine ed essenza della society coniugale, „Divus Thomas” 56 (1953), s. 347.

${ }^{28}$ L. Świto, „Exclusio boni prolis”..., s. 12.

${ }^{29}$ Por. B. Inlender, Cel małżeństwa $w$ aspekcie naturalnym $i$ nadprzyrodzonym, „Ateneum Kapłańskie” 62 (1970) t. 75 z. 1, s. 46-47; W. Skrzydlewski, Problem celów małżéstwa, „Analec- 
o wartości samego małżeństwa i dawało moralne uprawnienie do czynnego pożycia seksualnego ${ }^{30}$. Bonum prolis u biskupa z Hippony - polegające, zgodnie z jego słowami, na tym, ażeby potomstwo było z miłością przyjęte (amanter suscipiatur), chętnie wykarmione (benigne nutriatur) i religijnie wychowane (religiose educetur) - służyło przede wszystkim usprawiedliwieniu małżeństwa i jego aktów ${ }^{31}$. Nie można jednak powiedzieć, że było czymś absolutnie złym. W De coniugis adulternis Augustyn pisze, że małżeństwo, jak wszystko, pochodzi od Boga, a Ten stworzył wszystko dobrym. Nadto dobro to ma charakter naturalny i opiera się na jedności serc i duchowej miłości dwojga ludzi. Z niego też, jako dobra per se, wynikają inne wartości, które nie są czymś zewnętrznym w stosunku do małżeństwa, lecz zawierają się w nim samym, tj. bonum prolis, fidei et sacramenti ${ }^{32}$.

Taka doktryna na dobre zagościła w kanonistyce ${ }^{33}$. Rozwijali ją liczni autorzy średniowieczni, jak chociażby Piotr Lombard, Piotr Damian, Piotr Abelard, św. Bonawentura ${ }^{34}$ i Anzelm z Laon ${ }^{35}$. Jednak pełny wykład na temat dóbr małżeńskich daje św. Tomasz z Akwinu. Z jego Supplementum do Summy teologicznej jasno wynika, że dobra małżeńskie należy widzieć raczej jako wartości własne (naturalne). Nie są one jakimś dodatkiem, lecz należą do natury małżeństwa, są jego dobrami własnymi i same stanowią o jego wartości ${ }^{36}$. To przez nie się realizuje i dzięki nim posiada rację istnienia: „Dicendum, quod ista bona matrimonium honestant, sunt de ratione matrimonii: et ideo indiget eis exterioribus quibusdam ad hoc honestandum,

ta Cracoviensia" 3 (1971), s. 323-324.

${ }^{30}$ Por. św. Augustyn, De bono coniugali, PL 40, vi, 6, s. 378; De Gen. ad litterem, IX, 7, 12, PL 34, s. 397.

${ }^{31}$ Por. L. Świto, „Exclusio boni prolis”..., s. 13.

${ }^{32}$ Por. G. Leszczyński, Pojęcie „bonum coniugum”..., s. 104.

33 Por. L. Świto, „Exclusio boni prolis”..., s. 13.

${ }^{34}$ Por. Bonaventura, Sententiae IV, d. 31, a. 1, q. 3.

35 Por. P. Pampaloni, Il matrimonio nella scolastica, w: Enciclopedia del matrimonio, a cura di T. Goffi, wyd. 3, Brescia 1968, s. 324; U. Navarrete, Structura iuridica matrimonii secundum Concilium Vaticanum II, Romae 1994, s. 25.

${ }^{36}$ Por. W. Skrzydlewski, Problem celów małżeństwa, s. 326-327; L. Świto, „Exclusio boni prolis"..., s. 14; J. Hendriks, Diritto matrimoniale. Commentato ai canoni 1055-1165 del codice di diritto canonico, Milano 1999, s. 29; C. Burke, „Bonum coniugum” e il „bonum prolis”: fini o proprietà del matrimonio?, „Apollinaris” 62 (1989) nr 3-4, s. 567-568. 
sed quasi causantibus in ipso honestatem, quae ei secundum se competit" ${ }^{37}$. $\mathrm{W}$ ten sposób, jak stwierdzają znawcy tematu, Akwinata połączył dobra małżeńskie z konkretnymi działaniami małżeństwa, stojąc na stanowisku, że głównym zadaniem małżeństwa jest zrodzenie i wychowane potomstwa ${ }^{38}$. Jest to cel nadrzędny, gdyż odnosi się do dobra ludzkości, służąc zachowaniu jego gatunku. Dobro zaś wspólne należy przedkładać nad własne. W ten oto sposób św. Tomasz dokonał przejścia z płaszczyzny wartości małżeństwa na płaszczyznę celów i zadań, natomiast pojęcie bonum prolis połączył z zadaniem zrodzenia i wychowania potomstwa ${ }^{39}$. Co ważne, dokonał istotnego rozróżnienia, stwierdzając, „że potomstwo może być rozważane dwojako: po pierwsze, co do swej istoty (in se ipso), a więc w odniesieniu do używania małżeństwa, dzięki któremu powstaje potomstwo; po drugie, jako istniejące ze swej zasady (in suo principio), co oznacza, że za potomstwo przyjmuje się intencję dotyczącą posiadania go (ut pro prole accipiatur intentio prolis), bez której małżeństwo nie może istnieć. W związku z tym bonum prolis należało łączyć nie z konkretnie zrodzonym potomstwem, ale z intencją przyjęcia potomstwa, gdyż „sine intentione prolis matrimonium esse non potest" ${ }^{\circ}$.

Ukoronowaniem dorobku dotychczasowej kanonistyki był kodeks prawa kanonicznego z 1917 roku $^{41}$. Kan. 1081 $\$ 2$ postanawiał, że zgoda małżeńska jest aktem woli, przez który każda ze stron otrzymuje i przekazuje sobie nawzajem, dożywotne i ekskluzywne, prawo do ciała (ius in corpus). Oczywiście chodzi o akty, które ze swej natury są zdolne do wydania potomstwa ${ }^{42}$. Zatem ius in corpus jako istotny element zgody małżeńskiej utożsamia się po części z celem małżeństwa, czyli ze zrodzeniem i wychowaniem

${ }^{37}$ Św. Tomasz z Akwinu, Summa Theologica. Supplementum, w: Św. Tomasz z Akwinu, Opera omnia ad fidem optimarum editionum accurrate recognita, Parmae 1862-1873, q. 49, a. 2.

${ }^{8}$ Por. Św. Tomasz z Akwinu, Summa Theologica. Supplementum, 41, q. 49, a. 2: „In prole non solum intelligitur procreatio prolis, sed etiam educatio ipsius, ad quam sicut ad finem ordinatur tota communicatio operum quae est inter virum et uxorem inquantum sunt matrimonio coniuncti".

39 Por. L. Świto, „Exclusio boni prolis”..., s. 14.

${ }^{40}$ L. Świto, „Exclusio boni prolis”..., s. 14-15.

${ }^{41}$ Szerzej na ten temat: R. Wierzchanowski, „Bonum coniugum” $i$ „bonum prolis” jako przedmiot symulacji zgody matżeńskiej (kan. $1101 \$ 2$ KPK), „Teologiczne Studia Siedleckie” 10 (2013), s. 74-78.

42 „Consensus matrimonialis est actus voluntatis quo utraque pars tradit et acceptat ius in corpus, perpetuum et exclusivum, in ordine ad actus per se aptos ad prolis generatione”. 
potomstwa ${ }^{43}$. Dobra małżeńskie, $\mathrm{w}$ tym także bonum prolis jako elementarna część i konsekwencja ius in corpus, nabrały zobowiązującego charakteru. To niewątpliwie przyczyniło się do tego, że doktrynę o dobrach wypływających $\mathrm{z}$ małżeństwa stawiano w relacji do jego ważności ${ }^{44}$. $Z$ takiego ujęcia fundamentalnych elementów instytucji małżeństwa wyrastają jego cele. Kodeks z 1917 roku mówi o nich w kan. $1013 \$ 1$, gdy stwierdza: „Matrimonii finis primarius est procreatio atque educatio prolis: secundarius mutuum adiutorium et remedium concupiscentiae“. Według takiej hierarchii celów to właśnie wydanie i wychowanie potomstwa otrzymało status pierwszorzędny. Dalej zaś znajduje się wzajemna pomoc i zaspokojenie popędu. Trzeba też dodać, że kodeks jednoznacznie wiąże z dobrem potomstwa obowiązek jego wychowania, rozumianego jako dalszy etap wydawania na świat potomstwa (element educatio jawi się jako specyficzny etap generatio dla Kościoła i społeczeństwa). Temu także służy motuum adiutorium rozumiana jako wzajemna pomoc w relacjach wewnątrzmałżeńskich i rodzicielskich. Małżonkowie jako rodzice są odpowiedzialni za doprowadzenie potomstwa do pełnej samodzielności. Dotyczy to wszystkich wymiarów życia dziecka. W tym kontekście wypowiada się kan. $1113^{45}$, który nakłada na rodziców obowiązek wychowania potomstwa na płaszczyźnie religijnej i moralnej, fizycznej i obywatelskiej. Użyty tam zwrot gravissima obligatione („poważny obowiązek”) nie tylko służy podkreśleniu odpowiedzialności rodzicielskiej, lecz także odzwierciedla stosunek ustawodawstwa kościelnego do tego wszystkiego, co kryje się pod znaczeniem terminu bonum prolis.

Mając na uwadze treść kan. 1081 \$2 i $1013 \$ 1$ KPK Z 1917 roku z łatwością można zauważyć pewną słabość obowiązującego wtedy unormowania. Aby to dostrzec trzeba przywołać normę prawną wyrażoną w kan. $1086 \$ 2$. Brzmiał ona następująco: „At si alterutra vel utraque pars positivo voluntatis actu excludat matrimonium ipsum, aut omne ius ad coniugalem actum, vel essentialem aliquam matrimonii proprietatem, invalide contrahit". Co oznacza, że w sytuacji, kiedy jedna ze stron lub też obie strony pozytywnym aktem

${ }_{43}$ Por. H. Stawniak, Uprawnienie - obowiązek zrodzenia i wychowania potomstwa w świetle kanonicznego prawa matżeńskiego, „Prawo Kanoniczne” 32 (1989) nr 3-4, s. 126.

${ }_{44}$ Por. S. Biskupski, Prawo małżeńskie Kościoła rzymskokatolickiego, t. 1, Warszawa 1956, s. 286; M. Żurowski, Uprawnienia do wspótuczestnictwa w kościelnej wspólnocie wspólnot, Warszawa 1979, s. 124.

45 „Parentes gravissima obligatione tenentur prolis educationem tum religiosam et moralem, tum physicam et civilem pro viribus curandi et etiam temporali eorum bono providendi”. 
woli wykluczą małżeństwo jako takie albo wszelkie prawo do małżeńskiego współżycia, lub też jakiś istotny przymiot małżeństwa, to wtedy zawierają małżeństwo nieważnie. Ponieważ w tym okresie kanonistyka utożsamiała istotny element zgody małżenskiej z ius in corpus, stąd ewentualne wykluczenie skutków płodnych aktów małżeńskich nie sprawiało nieważności małżeństwa w rozumieniu kan. $1086 \$ 2^{46}$. Naturalnie przytoczony wcześniej kan. $1013 \$ 1$ KPK Z 1917 roku podkreślał obowiązek zrodzenia i wychowania potomstwa, lecz w odniesieniu do pierwszorzędnego celu małżeństwa, a nie istotnego elementu. To powodowało, że ówczesne trybunały zajmujące się sprawami ważności małżeństw koncentrowały swoją uwagę na przekazaniu w akcie zgody małżeńskiej prawa do ciała (oczywiście w odniesieniu do płodnych aktów małżeńskich). To też było przedmiotem ich dowodzenia. Ewentualny brak przekazania ius in corpus powodował nieważność konsensusu, ale wykluczenie skutków płodnych aktów małżeńskich już $n^{4}{ }^{47}$. Gdyby zatem kontrahent, zawierając małżeństwo, pozytywnym aktem woli wykluczył możliwość przyjścia na świat dziecka (np. przez działania aborcyjne lub wczesnoporonne), to według ówczesnego prawa zawierałby małżeństwo ważnie ${ }^{48}$. Oczywiście trudno nam dzisiaj wyobrazić sobie taką sytuację, ale pokazuje to konieczność prowadzenia badań i ewentualnego uściślania niektórych terminów. Badając tę sprawę, Lucjan Świto stwierdził: „O samej prokreacji, do której odnosi się pierwszorzędny cel małżeństwa, wspomina kan. $1013 \$ 1$ KPK Z 1917 roku. Ten zaś nie jest opatrzony normą unieważniającą. Również w kan. 1092 n. 2 KPK Z 1917 roku, który istotowo nie różnił się z kan. $1086 \$ 2$ KPK Z 1917 roku, gdyż mówił o nieważności małżeństwa w przypadku postawienia warunków przeciwnych istocie małżeństwa, nie mówi się, że nieważne małżeństwo spowodowane jest przez postawienie warunku przeciwnego zrodzeniu potomstwa, lecz tylko przez postawienie warunku przeciwnego istocie małżeństwa. Nie należy zaś do istoty małżeństwa zrodzenie potomstwa, lecz wzajemne przekazanie i przyjęcie prawa do aktów małżeńskich zdatnych ze swej natury do zrodzenia potomstwa" ${ }^{49}$.

${ }^{46}$ Por. H. Stawniak, Uprawnienie - obowiązek..., s. 127; L. Świto, „Exclusio boni prolis”..., S. 16.

47 Por. U. Navarrete, De iure ad vitae communionem: observationes ad novum schema canonis 1086 \$ 2, „Periodica de Re Morali” 66 (1977), s. 249-270.

${ }^{48}$ Por. A. De Smet, Tractatus theologico-canonicus de sponsalibus et matrimonio, Burgis 1927, s. 130; A. Vermeersch, I. Creusen, Epitome iuris canonici, t. 2, Mechliniae 1954, s. 271-272.

${ }^{49}$ L. Świto, „Exclusio boni prolis”..., s. 18. 


\section{W poszukiwaniu nowego ujęcia}

Analizując historię rozumienia boni prolis w świadomości Kościoła, nie można pominąć encykliki papieża Piusa XI Casti connubii z 1930 roku. To dokument wielkiej wagi, dotyczący istoty małżeństwa, jego godności, korzyści i dobrodziejstw. Zawarta w nim treść opiera się w znacznej mierze na schemacie trzech dóbr św. Augustyna ${ }^{50}$. Zawiera jednak pewne novum, które postaram się ukazać.

Już na samym początku, jak gdyby dla ustawienia pewnego punktu odniesienia, bonum prolis otrzymuje uprzywilejowane miejsce w hierarchii dóbr małżeństwa. W swojej argumentacji papież odwołuje się do porządku naturalnego, wskazanego przez Boga i potwierdzonego w nauczaniu Kościoła: „Pierwsze więc miejsce pomiędzy dobrami małżeństwa zajmuje potomstwo. I zaprawdę sam Stwórca rodzaju ludzkiego, który w dobroci swej w dziele rozkrzewiania życia postanowił ludzi użyć jako pomocników swych, nauczał tego, kiedy, ustanawiając w raju małżeństwo, powiedział do prarodziców naszych, a przez nich do przyszłych małżonków: «Roście i mnóżcie się, i napetniajcie ziemię». To samo znajduje św. Augustyn w słowach św. Pawła Apostoła do Tymoteusza: «Że celem rodzenia zawiera się małżeństwo», świadczy Apostoł w ten sposób: Chcę, aby młodsze szły za mąż. A jakoby wtrącono pytanie: Dlaczego? dodaje zaraz: «Aby dzieci rodziły, stawały się paniami domu»"51. To jednak nie wszystko. O ile kan. $1013 \$ 1$ KPK Z 1917 roku mówił ogólnie o procreatio atque educatio prolis, to w tym wypadku papież jasno wyznacza płaszczyzny owego wychowania. Obejmuje ono dwie sfery: duchową i fizyczną. Wszystko po to, aby nowe pokolenie nie tylko służyło rodzinie, lecz także nieustannie „rodziło” się dla Boga, Kościoła i ojczyzny ${ }^{52}$. Stąd też należy wnioskować, że dobro potomstwa, jako istotny element przedmiotu zgody małżeńskiej, obejmuje wzajemne prawo do aktów małżeńskich. One to ze swej natury prowadzą do zrodzenia potomstwa

${ }^{50}$ Por. H. Stawniak, Uprawnienie - obowiązek..., s. 128.

${ }_{51}$ Pius XI, enc. Casti connubii, 1.

${ }^{52}$ „Rodzice chrześcijańscy niech zastanowią się również nad tem, że zadaniem ich jest nie tylko rozradzanie i zachowanie rodzaju ludzkiego na ziemi, [...] lecz powiększenie liczby dzieci Kościoła Chrystusowego [...]. I oboje małżonkowie uważać będą te dzieci, które skorem i wdzięcznem przyjęli sercem z ręki Bożej, jako skarb, powierzony im przez Boga, który zużyją nie tylko na korzyść swoją i ziemskiej swej ojczyzny, lecz który w dzień zdania rachuby z zyskiem Bogu oddadzą" (Pius XI, enc. Casti connubii, 1). 
i zakładają w sobie jego wszechstronną edukację․ W tym też kontekście widziane jest bonum fidei. Obejmuje ono małżeńską wierność i miłość, które w nauczaniu papieża są niezbędne do właściwego formowania małżonków i ich dzieci. W tym miejscu pojawia się owo novum Piusa XI, który stwierdza, że obok zrodzenia i wychowania potomstwa, to właśnie wzajemna pomoc małżonków jest „najważniejszym czynnikiem i celem małżeństwa" ${ }^{4}$. Takie słowa, w kontekście dotychczasowej doktryny, są dość zaskakujące. Z jednej strony Pius Xı podtrzymuje naukę o pierwszorzędnym znaczeniu potomstwa, z drugiej dowartościowuje miłość małżeńską i wypływający z niej obowiązek wzajemnego doskonalenia się. Jest to więc drugi cel, ale o pierwszorzędnym znaczeniu $^{55}$. Wynika $\mathrm{z}$ tego, że małżeństwo jako totius vitae communio nie może ograniczać się do obowiązku prokreacji. Trzeba widzieć w nim wszystkie osoby potrzebujące wsparcia i miłości. Dobra potomstwa nie można oddzielać od dobra stron, bonum prolis od bonum fidei, gdyż wszyscy jako uczestnicy wspólnego życia tworzą rzeczywistość rodziny ${ }^{56}$. To pierwsze tak personalistyczne spojrzenie na instytucję małżeństwa było dla wielu kłopotliwe do tego stopnia, że wspomniany passus pomijali w tłumaczeniach ${ }^{57}$.

Trzeba przyznać, że doktryna encykliki Casti connubii była dość odważnym krokiem w świecie, gdzie kanonistyka tradycyjna zapuściła głębokie korzenie. Pozwoliło to na zbliżenie dwóch nurtów wytworzonych w teologiczno-prawnej teorii małżeństwa oraz narodzenie się krytycznego spojrzenia na dotychczasową doktrynę małżeńską ${ }^{58}$. Stanowisko Piusa XI stało się inspiracją dla wielu autorów, którzy postanowili zrewidować dotychczasowe rozumienie celów i dóbr małżeńskich. Jak się okazało, niektórzy z nich zabrnęli za daleko, zmuszając tym samym Kościół do ostrej reakcji i prostowania błędów ${ }^{59}$.

53 Por. H. Stawniak, Uprawnienie - obowiązek..., s. 128.

${ }^{54}$ Pius XI, enc. Casti connubii, 2; por. H. Stawniak, Problem „bonum coniugum”, „Prawo Kanoniczne" 32 (1989) nr 1-2, s. 100-104.

55 Por. H. Stawniak, Uprawnienie - obowiązek..., s. 129.

${ }^{56}$ Tekst autentyczny stwierdza: „Quot vero quantaque ex matrimonii indissolubilitate fluant bona, eum fugere non potest qui vel obiter cogitet sive de coniugum prolisque bono sine de humanae societatis salute” (Pius XI, enc. Casti connubii, „Acta Apostolicae Sedis” [dalej AAS] 22 [1930], s. 553).

57 Por. H. Stawniak, Uprawnienie - obowiązek..., s. 129.

${ }^{58}$ Por. H. Stawniak, Uprawnienie - obowiązek..., s. 129.

59 Przykładem są chociażby skrajnie personalistyczne poglądy Huberta Domsa i Norberta Rocholla. Ogólnie mówiąc, zarzucili oni dotychczasową doktrynę, twierdząc, że współżycie 


\section{Sobór Watykański II i nowa kodyfikacja}

Niewątpliwie przełomowym momentem w dyskusji nad dobrami i celami małżeństwa był sobór watykański II. Ojcowie soborowi postanowili nie rozstrzygać, który z celów jest ważniejszy, lecz ukazać w sposób całościowy instytucję małżeństwa. Określając małżeństwo jako intima communitas vitae et amoris coniugalis ${ }^{60}$, Kościół odstąpił od jedynie prokreacyjnej, a zarazem jurydycznej wizji małżeństwa. Podkreślił, że małżeństwo chrześcijańskie to wspólnota miłości, która nie istnieje bez międzyosobowych więzi i daru $\mathrm{z}$ siebie $^{61}$. Miłość posiada aspekt cielesny (tak charakterystyczny dla ius in corpus) oraz duchowy - oznacza także relację międzyosobową, uświęconą w sakramencie małżeństwa. Wobec takiego personalizmu dotychczasowy, pierwszorzędny cel - ordinatio ad prolem - może być interpretowany i rozumiany tylko w kontekście małżeństwa ujmowanego w kategoriach wspólnoty życia i miłości ${ }^{62}$. Nie zadeklarowano, że zrodzenie i wychowanie potomstwa jest pierwszorzędnym celem małżeństwa, ale stwierdzono jedynie, że z natury swej jest ono nastawione na ten cel. Oznacza to, że istnieją jeszcze inne cele równoległe, których nie można kwestionować (non posthabitis ceteris matrimonii finibus $\left.{ }^{63}\right)$. Małżonkowie przez miłość i zaufanie budują wspólnotę życia. Jej nieodłącznym elementem jest otwartość na dar potomstwa,

de facto nie służy prokreacji, lecz małżonkom: umacnia ich miłość, jednoczy i daje przyjemność. Wobec takiego stanowiska, w którym potomstwo jest czymś wtórnym, Kościół nie mógł przejść obojętnie. Stąd Kongregacja Świętego Oficjum wydała 1 kwietnia 1944 roku z polecenia Piusa XII Decretum de finibus matrimonii potępiający takie twierdzenia. Zob. AAS 36 (1944), s. 103. Więcej: W. Góralski, Studia nad matżeństwem i rodziną, Warszawa 2007, s. 122-123.

${ }^{60}$ Sobór Watykański II, konst. Gaudium et spes, 48 (tekst autentyczny: AAS 58 [1966], s. 1067$)$.

${ }^{61}$ Por. H. Stawniak, Wspólnotowy charakter małżeństwa $w$ świetle nowego Kodeksu Prawa Kanonicznego, „Prawo Kanoniczne” 31 (1988) nr 3-4, s. 116; J. Rybczyk, Projekt reformy prawa małżeńskiego (część I - kanony 1012-1034), „Prawo Kanoniczne” 20 (1977) nr 1-2, s. 204.

${ }^{62}$ Por. G. Leszczyński, Pojęcie „bonum coniugum”..., s. 109; Z. Grocholewski, Sakrament małżeństwa: fundament teologiczny prawodawstwa kościelnego, „Prawo Kanoniczne” 40 (1997) nr 1-2, s. 184-192. Podobną wizję małżeństwa znajdziemy w encyklice Pawła vi Humanae vitae, 8: „Quocirca per mutuam sui donationem, quae ipsorum propria est et exclusoria, coniuges illam persequuntur personarum communionem, qua se invicem perficiant, ut ad novorum viventium procreationem et educationem cum Deo operam socient" ( 25 VII 1968, AAS 6o [1968], s. 485-486). Por. K. Wojtyła, Miłość i odpowiedzialność, Lublin 1986, s. 42.

${ }^{63}$ Sobór Watykański II, konst. Gaudium et spes, 48. 
w którym owa wspólnota najpełniej się wyraża i realizuje ${ }^{64}$. Wielu badaczy jest zdania, że zwrot non posthabitis ceteris matrimonii finibus ukształtował się w wyniku dyskusji soborowej, która chroniła się przed zajmowaniem skrajnych stanowisk - jakoby potomstwo było jedynym celem małżeństwa oraz nie dość wyraźnego wydobycia potomstwa jako istotnego celu ${ }^{65}$. Należy pamiętać, że dokumenty soborowe nie kwestionują bonum prolis, ale jedynie ustawiają je we właściwym świetle. To dobro podstawowe, lecz nie wyłączne. Bez otwartości na potomstwo miłość małżeńska traci sens, stając się jedynie wyrazem egoizmu. A skoro tak, to swoją istotę w takich warunkach straciłaby sama instytucja małżeństwa, która ograniczałaby się jedynie do legalizacji swobodnego i nieodpowiedzialnego użycia drugiej osoby. Nowe życie to najcenniejszy dar, który rodzicom przynosi wiele dobra $^{66}$. W przekazywaniu tego życia małżonkowie są współpracownikami Stwórcy, z tym że „nie są narzędziami, lecz interpretatorami pełnego sensu miłości stwórczej i zbawczej Boga" ${ }^{67}$.

Odbiciem soborowej nauki jest kodeks prawa kanonicznego z 1983 roku. W kan. $1055 \$ 1$ stwierdza, że małżeństwo jest „przymierzem, przez które mężczyzna i kobieta tworzą ze sobą wspólnotę całego życia, skierowaną ze swej natury do dobra małżonków oraz do zrodzenia i wychowania potomstwa, i że małżeństwo między ochrzczonymi zostało podniesione przez Chrystusa Pana do godności sakramentu"68.

Według tej definicji małżeństwo to przymierze znajdujące swoją najwyższą manifestację w posiadanym potomstwie, a akt seksualny małżonków to znak wzajemnego i trwałego oddania się osób ${ }^{69}$. Zgodnie z kan. $1057 \$ 2$

${ }^{64}$ Por Sobór Watykański II, konst. Gaudium et spes, 48; Z. Grocholewski, Sakrament matżeństwa..., s. 180-182.

${ }^{65}$ Por. H. Stawniak, Uprawnienie - obowiązek..., s. 132; U. Navarrete, Structura iuridica matrimonii, s. 382.

${ }^{66}$ Por. Sobór Watykański II, konst. Gaudium et spes, 50; H. Stawniak, Jedność i nierozerwalność matżeństwa, s. 113.

${ }^{67}$ H. Stawniak, Uprawnienie - obowiązek..., s. 133.

${ }^{68}$ Tekst łaciński stwierdza: „Matrimoniale foedus, quo vir et mulier inter se totius vitae consortium constituunt, indole sua naturali ad bonum coniugum atque ad prolis generationem et educationem ordinatum, a Christo Domino ad sacramenti dignitatem inter baptizatos evectum est" (kan. 1055 \$1 KPK Z 1983).

${ }^{69}$ Por. R. Sobański, Symulacja częściowa w ujęciu kan. $1086 \$ 2$ a nauka o małżeństwie Konstytucji „Gaudium et spes”, „Śląskie Studia Historyczno-Teologiczne” 2 (1969), s. 31; L. Świto, „Exclusio boni prolis”..., s. 30. 
istotą związku małżeńskiego nie jest już tylko prawo do ciała, lecz wzajemne przekazanie siebie, i to we wszystkich sferach: intelektualnej, emocjonalnej, duchowej i seksualnej (sese mutuo tradunt et accipiunt) ${ }^{70}$. Mężczyzna i kobieta oddają sobie to wszystko, czym są, co mają najcenniejszego i co wyraża ich istotę. Tak rozumiana wspólnota życia małżeńskiego sama ukierunkowuje się ku potomstwu, które jawi się jako widzialny owoc miłości, źródło radości rodzicielskiej i spoiwo cementujące związek małżeński. W chwili konstytuowania się małżeństwa nie może zabraknąć w akcie woli, owego ukierunkowania na potomstwo. To ono zakłada w sobie cielesne oddanie i otwartość na akt seksualny zdolny do zrodzenia dziecka - czyli stanowi jeden $\mathrm{z}$ istotnych elementów małżeństwa. Wobec tego ustawodawca nie dopuszcza sytuacji, gdy nupturienci, wyrażając zgodę małżeńską wykluczaliby to wszystko, co prowadzi do pojawienia się potomstwa (symulacja). Stąd bonum prolis trzeba utożsamiać $\mathrm{z}$ wewnętrznym ukierunkowaniem na potomstwo. Ewentualna nieważność małżeństwa nie tyle wypływa wprost z wykluczenia zewnętrznego celu małżeństwa - tzn. jakiegoś konkretnego, poczętego i zrodzonego dziecka, ale łączy się z brakiem wewnętrznego nastawienia na potomstwo (ordinatio ad prolem) - $\mathrm{z}$ racji nieprzekazania należnego prawa do aktu małżeńskiego, dzięki któremu w zwykłych okolicznościach następuje poczęcie i zrodzenie potomstwa ${ }^{71}$. „Nowy kodeks łączy więc w jedno intencję przyjęcia potomstwa $\mathrm{z}$ naturalnie podjętym małżeńskim aktem obdarowania się seksualnego"72. Dziecko, jako konsekwencja aktu ludzkiego, jest celem małżeństwa, do którego każda ze stron ma prawo. Oznacza to, że każdy z małżonków może żądać od drugiego owego „ukierunkowania” i pozytywnego nastawienia do potomstwa. To prosta konsekwencja wyrażonej zgody małżeńskiej ${ }^{73}$. Dzieje się tak, gdyż ukierunkowanie ku potomstwu, jako istotny element małżeństwa, należy do przedmiotu formalnego zgody małżeńskiej, która $\mathrm{z}$ kolei konstytuuje samo małżeństwo ${ }^{74}$. W tym samym

${ }^{70}$ Por. U. Navarrete, Structura iuridica matrimonii..., s. 148-167.

${ }^{71}$ Por. L. Świto, „Exclusio boni prolis”..., s. 31.

72 L. Świto, „Exclusio boni prolis”..., s. 31.

${ }^{73}$ Por. Z. Zdybicka, Cel, w: Encyklopedia katolicka, t. 2, kol. 1385-1386.

${ }^{74}$ Por. E. Graziani, Essenza del matrimonio e definizione del consenso, w: La nuova legislazione matrimoniale canonica (Studi Giurdici, 10), Città del Vaticano 1986, s. 29; R. Sztychmiler, Implikacje procesowe ujęcia celów małżeństwa w Kodeksie Prawa Kanonicznego z 1983 r., w: W. Góralski, R. Sztychmiler, Przymierze matżeńskie, Lublin 1993, s. 77; H. Stawniak, Niemoc płciowa jako przeszkoda do małżeństwa. Ewolucja czy zmiana koncepcji?, Warszawa 20oo, s. 343. 
tonie wypowiada się większość audytorów rotalnych, jak np. Mario Pompedda, Kenneth Boccafola, Luigi Civili czy Antoni Stankiewicz. Nie można wykluczyć w akcie wyrażania zgody ukierunkowania ku potomstwu, bez jednoczesnego spowodowania jej nieważności ${ }^{75}$.

Warto tu także przytoczyć kan. 1135 KPK z 1983 roku, który wyraźnie stwierdza, że „każdemu z małżonków przysługują jednakowe obowiązki i prawa w tym, co dotyczy wspólnoty życia małżeńskiego", i to w szczególności prawa i obowiązki do aktów ludzkich właściwych wspólnocie małżeńskiej, ze swej natury zdatnych do zrodzenia potomstwa, na które przecież małżeństwo jest ukierunkowane i dzięki którym małżonkowie stanowią jedno ciało ${ }^{76}$. Stąd wykluczenie prawa do aktów małżeńskich będzie również wykluczeniem dobra potomstwa (boni prolis), a to z kolei pociąga za sobą poważne skutki prawne (kan. $1101 \$ 2$ KPK Z 1983). Potwierdzeniem tych tez jest instrukcja Kongregacji Doktryny Wiary Donum vitae z 22 lutego 1987 roku, która wobec pewnych wątpliwości przypomina wiernym, że małżeństwo daje małżonkom obiektywne prawo do spełniania aktów seksualnych, ukierunkowanych na zrodzenie potomstwa ${ }^{77}$. To zdanie w jednoznaczny sposób określa naturę aktu małżeńskiego i jego elementy. Trzeba o tym pamiętać, gdyż w historii pojawiało się wiele redukcjonistycznych koncepcji aktów małżeńskich ${ }^{78}$. Oznacza to, że nawet jeśli nupturienci, expressis verbis, w wyrażanym akcie zgody małżeńskiej nie wykluczają samego współżycia, ale wprost samo potomstwo, jako oczywisty skutek podjętych działań, to zawierają małżeństwo

75 Por. R. Sztychmiler, Implikacje procesowe ujęcia celów małżeństwa ..., s. 89; L. Świto, „Exclusio boni prolis"..., s. 31-32.

${ }^{76}$ Por. L. Świto, „Exclusio boni prolis”..., s. 34; kan. $1055 \$ 1,1061 \$ 1 \mathrm{KPK}$ Z 1983 roku.

77 Por. Congregatio pro Doctrina Fidei, Instructio de observantia erga vitam humanam nascentem deque procreationis dignitate tuenda, (Donum vitae), AAs 80 (1988), s. 97, przekład polski: Posoborowe dokumenty Kościoła Katolickiego o małżeństwie i rodzinie, t. 1, Kraków 1999, s. 334.

${ }^{78}$ Dokładnie na ten temat pisze H. Stawniak, który wymienia następujące teorie aktu małżeńskiego: copula fecundativa (do istotnych elementów aktu małżeńskiego oprócz erekcji, penetracji i ejakulacji wymaga się actio humana $i$ actio naturale), copula initiva (wg tej koncepcji zjednoczenie cielesne nie ma na celu zrodzenia potomstwa, lecz budowanie unii międzyosobowej), copula satitiva (tu głównym celem aktu małżeńskiego było zaspokojenie popędu i przyjemność, czynnik prokreacyjny odsuwany był na bok), copula perfecta (tu zjednoczenie małżonków jest wyrazem miłości i wspólnoty, a akt małżeński zawsze ukierunkowany jest na zrodzenie potomstwa rozumianego w kategoriach daru). Zob. H. Stawniak, Niemoc ptciowa jako przeszkoda do małżeństwa..., s. 147-154. 
nieważnie. Nie można bowiem pogodzić aktów małżeńskich z jednoczesnym podjęciem działań mających na celu przeciwdziałanie poczęciu potomstwa i jego narodzeniu (np. środki wczesnoporonne). W tym sensie ius ad prolem małżonków zawiera w sobie ius vitae potomstwa ${ }^{79}$. Podobnie rzecz ma się z tzw. zapłodnieniem in vitro. Jeśli bowiem jedna ze stron albo obydwie, pozytywnym aktem woli, w akcie zgody małżeńskiej, wykluczają naturalny sposób poczęcia, ograniczając się wyłącznie do sztucznego zapłodnienia, to zawierają małżeństwo nieważnie. Wynika to nie tylko z założeń moralno-doktrynalnych, lecz również z tego, że w takiej sytuacji brak jest rzeczywistego wzajemnego przekazania i przyjęcia. Co więcej, współkontrahent niesprawiedliwie pozbawiony jest prawa do małżeństwa i ojcostwa naturalnego, a zrodzone w ten sposób potomstwo nie jest w sensie ścisłym owocem małżeństwa, choć jest dzieckiem obojga stron (przy zapłodnieniu homologicznym $)^{80}$. Tematyka ta jest bardzo złożona i z pewnością domaga się osobnego potraktowania.

Trzeba także dodać, że prawodawca kościelny z dobrem potomstwa łączy obowiązek jego wychowania ${ }^{81}$. Nie jest to jakiś dodatek do bonum prolis, ale jego integralny element. Jak wielką uwagę Kościół przykłada do wychowania, może świadczyć fakt, że Sobór Watykański II mówi o nim aż w jedenastu dokumentach. Według ojców soborowych rodzina to "matka i żywicielka wychowania”, „szkoła bogatszego człowieczeństwa”. To w niej dziecko startuje do życia, kształtuje się jego porządek moralny i religijny, intelektualny i uczuciowy, indywidualny i społeczny. Stąd apeluje do rodziców, by nie tylko dbali o spawy materialne ${ }^{82}$, lecz by od najmłodszych lat budzili w dzieciach wiarę i miłość, stając się dla nich „pierwszymi głosicielami wiary i wychowawcami" ${ }^{83}$. W praktyce znajduje to wyraz w obrzędzie zawierania małżeństwa, gdy asystujący przy jego zawieraniu pyta: „Czy chcecie z miłością

79 Por. Katechizm Kościoła Katolickiego, Poznań 1994, 2378; Pius XII, Allocutiones, 19 V 1956, AAs 48 (1956), s. 471.

${ }^{80}$ Por. W. Góralski, Wykluczenie dobra potomstwa $w$ nowszym orzecznictwie rotalnym, „Ius Matrimoniale" 9 (2004), s. 131-132.

${ }^{81}$ Por. Sobór Watykański II, konst. Gaudium et spes, 48; Jan Paweł II, List do kobiet A ciascuna di Voi, 8; J. Krzywda, Istotnie obowiązki małżeńskie w przemówieniach Jana Pawła II, „Ius Matrimoniale" 1 (1996), s. 96-99.

${ }^{82}$ Por. Sobór Watykański II, dekl. Gravissimum educationis, 1-3.

${ }^{83}$ F. Macharski, Troska Kościoła o rodzinę, „Ateneum Kapłańskie” 62 (1970) t. 75 z. 1, s. 61-62. 
przyjąć i po katolicku wychować potomstwo, którym was Bóg obdarzy?" ${ }^{84}$. Podobny obowiązek wychowania katolickiego istnieje przy małżeństwach mieszanych, kiedy to prawo wymaga rękojmi od strony katolickiej. Ważność obowiązku wychowania dziecka $w$ duchu katolickim jest też zaznaczona w prawie karnym. W kan. 1366 KPK z 1983 roku prawodawca kościelny przewiduje cezurę lub inną sprawiedliwą karę dla rodziców, którzy oddają dzieci do chrztu lub wychowania w religii niekatolickiej. Stąd ewentualne wykluczenie tego obowiązku rzutuje na ważność umowy małżeńskiej ${ }^{85}$.

\section{Podsumowanie}

Przeprowadzona analiza pozwala na stwierdzenie, że dobro potomstwa w kanonicznym prawie małżeńskim zajmuje miejsce szczególne. Wynika to przede wszystkim z jego zakorzenienia w prawie Bożym, tak naturalnym, jak i pozytywnym. Dobrze tę prawdę odzwierciedla prawo rzymskie i przekaz biblijny. Ten ostatni stał się przedmiotem wielu analiz prowadzonych przez pisarzy wczesnochrześcijańskich i scholastycznych. Na wyróżnienie zasługuje tu przede wszystkim dorobek św. Augustyna, który jako pierwszy wyróżnił w doktrynie o małżeństwie trzy dobra: bonum prolis, bonum fidei i bonum sacramenti. Można powiedzieć, że właściwie cała późniejsza kanonistyka, w odniesieniu do poruszanego problemu, zajęła się dogmatyczno-prawną konkretyzacją tych dóbr, starając się ukazać ich treść, znaczenie dla wspólnoty małżeńskiej oraz sprecyzować, w jakich okolicznościach wykluczenie pozytywnym aktem woli jednego $\mathrm{z}$ tych dóbr powoduje nieważność zawieranego małżeństwa.

Ponadto całościowa synteza pozwala zobaczyć, jak zmieniało się rozumienie bonum prolis w świadomości Kościoła. Generalnie można stwierdzić, że zmiana akcentów przechodziła od wizji prokreacyjno-wychowawczej do personalistycznej, z tym, że dowartościowanie przez Sobór Watykański II dobra małżonków (bonum coniugum) w żaden sposobów nie umniejsza znaczenia i konieczności realizacji w małżeństwie drugiego (równorzędnego) celu, którym jest bonum prolis.

\footnotetext{
${ }^{84}$ Obrzędy sakramentu małżeństwa, Katowice 2007, s. 29.

${ }^{85}$ Por. K. Konieczny, Nieważność małżeństwa $z$ tytułu wykluczenia potomstwa, „Ateneum Kapłańskie" 50 (1958) t. 56 z. 3, s. 434.
} 


\section{Bibliografia}

Bonfante P., Istituzioni di diritto romano, Milano 1932.

Burke C., „Bonum coniugum” e il „bonum prolis”: fini o proprietà del matrimonio?, "Apollinaris" 62 (1989), s. 559-570.

Codex Iuris Canonici. Auctoritate Ioannis Pauli PP. II promulgatus. Kodeks prawa kanonicznego z przekładem polskim zatwierdzonym przez Konferencję Episkopatu Polski, Poznań 1984.

Congregatio pro Doctrina Fidei, Instructio de observantia erga vitam humanam nascentem deque procreationis dignitate tuenda, (Donum vitae), „Acta Apostolicae Sedis” 80 (1988), s. 97, przekład polski: Posoborowe dokumenty Kościoła Katolickiego o małżeństwie i rodzinie, t. 1, Kraków 1999, s. 309-343.

Góralski W., Ius matrimoniale. Ze studiów nad kościelnym prawem małżeńskim, t. 1, Lublin 1990.

Góralski W., Studia nad małżeństwem i rodzina, Warszawa 2007.

Góralski W., Wykluczenie dobra potomstwa w nowszym orzecznictwie rotalnym, „Ius Matrimoniale” 9 (2004), s. 115-136.

Graziani E., Essenza del matrimonio e definizione del consenso, w: La nuova legislazione matrimoniale canonica (Studi Giurdici, 10), Città del Vaticano 1986.

Hendriks J., Diritto matrimoniale. Commentato ai canoni 1055-1165 del codice di diritto canonico, Milano 1999.

Homerski J., Życie religijne wspólnoty małżeńskiej i rodzinnej w świetle tekstów biblijnych, „Zeszyty Naukowe Katolickiego Uniwersytetu Lubelskiego” 23 (1980) z. 3, 63-72.

Inlender B., Cel matżeństwa $w$ aspekcie naturalnym i nadprzyrodzonym, „Ateneum Kapłańskie" 62 (1970) t. 75 z. 1, s. 44-54.

Katechizm Kościoła Katolickiego, Poznań 1994.

Konieczny K., Nieważność małżeństwa z tytułu wykluczenia potomstwa, „Ateneum Kapłańskie" 50 (1958) t. 56 z. 3, s. 427-439.

Leszczyński G., Pojęcie „,bonum coniugum” w prawie małżeńskim Kościoła, „Śląskie Studia Historyczno-Teologiczne" 36 (2003) z. 1, s. 101-115.

Paweł vi, Encyklika Humanae vitae, 25 VII 1968, „Acta Apostolicae Sedis” 6o (1968), s. 481-503, przekł. polski: Posoborowe dokumenty Kościoła katolickiego o malżeństwie i rodzinie, t. 1, Kraków 1999, s. 21-42.

Pius XI, Encyklika Casti connubii, 31 XII 1930, „Acta Apostolicae Sedis” 22 (1930), s. 539-592, przekł. polski: Londyn 1945.

Romaniuk K., Małżeństwo i rodzina w Biblii, Katowice 1981. 
S. Thomas Aquinatis, Opera omnia ad fidem optimarum editionum accurate recognita, t. 1-25, Parmae 1862-1873.

Skrzydlewski W., Problem celów małżeństwa, „Analecta Cracoviensia” 3 (1971), s. 321-361.

Sobór Watykański II, Deklaracja o wychowaniu chrześcijańskim Gravissimum educationis, w: Sobór Watykański II, Konstytucje, dekrety, deklaracje, Poznań 2002, s. 314-324.

Sobór Watykański II, Konstytucja duszpasterska o Kościele w świecie współczesnym Gaudium et spes, w: Sobór Watykański II, Konstytucje, dekrety, deklaracje, Poznań 2002, s. 526-6o6.

Stawniak H., Problem „bonum coniugum”, „Prawo Kanoniczne” 32 (1989) nr 1-2, s. 97-118.

Stawniak H., Uprawnienie - obowiązek zrodzenia $i$ wychowania potomstwa $w$ świetle kanonicznego prawa małżeńskiego, „Prawo Kanoniczne” 32 (1989) nr 3-4, S. $125-142$.

Stawniak H., Wspólnotowy charakter małżeństwa $w$ świetle nowego Kodeksu Prawa Kanonicznego, „Prawo Kanoniczne” 31 (1988) nr 3-4, s. 109-130.

Suprema Sacra Congregatio S. Officci, Decretum de finibus matrimonii, 1 IV 1944, „Acta Apostolicae Sedis” 36 (1944), s. 103.

Sztychmiler R., Implikacje procesowe ujęcia celów małżeństwa w Kodeksie Prawa Kanonicznego z 1983 r., w: W. Góralski, R. Sztychmiler, Przymierze małżeńskie, Lublin 1993, s. 75-95.

Świto L., „Exclusio boni prolis” jako tytuł nieważności małżeństwa, Olsztyn 2003.

\section{Streszczenie}

Przeprowadzona analiza ukazuje swoistą ewolucję, jaką na przestrzeni wieków przeszło bonum prolis. Za punkt wyjścia obrano unormowania zawarte w prawie rzymskim oraz tradycji biblijnej. Ponadto w publikacji odwołano się do dorobku wielkich postaci Kościoła, takich jak św. Augustyn i św. Tomasz z Akwinu. To właśnie ten pierwszy wyróżnił w doktrynie o małżeństwie trzy dobra: bonum prolis, bonum fidei oraz bonum sacramenti. Augustyn szczególne miejsce przypisał dobru potomstwa, a to dlatego, że dzięki niemu małżeństwo otrzymuje status środka leczącego namiętności (remedium concupiscentiae). Następnie doktrynę tę podjęła kanonistyka wieków średnich, a jej najwybitniejszym reprezentantem stał się św. Tomasz. Jego zasługą było ustawienie dóbr małżeńskich na płaszczyźnie 
naturalnej. Według Akwinaty bonum prolis, bonum fidei i bonum sacramenti są dobrami przynależącymi z natury do małżeństwa, a zatem nie potrzebują żadnego, zewnętrznego usprawiedliwienia.

Z kolei kodeks prawa kanonicznego $\mathrm{z} 1917$ roku wiązał bonum prolis $\mathrm{z}$ ius in corpus (kan. $1081 \$ 2$ ), które przekazane i przyjęte w akcie zgody małżeńskiej miało charakter dozgonny i ekskluzywny, prokreacyjny i wspólnotowy. Z wszystkich celów małżeństwa to właśnie zrodzenie i wychowanie potomstwa otrzymało pierwszorzędny status, któremu dobro małżonków było podporządkowane. Takie ustawienie boni prolis szybko okazało się niewystarczające, a to dlatego, że nie brało pod uwagę sytuacji, w której małżonkowie posiadali intencję przeciwną zrodzeniu potomstwa (np. zamiar aborcji czy porzucenia dziecka), ale zarazem nie wykluczali prawa do aktów małżeńskich. Rozwiązanie tego problemu przyniosła najpierw encyklika Piusa XI Casti connubii, a następnie doktryna Soboru Watykańskiego II. Ten ostatni w konstytucji Gaudium et spes określił małżeństwo jako intima communitas vitae et amoris coniugalis. W ten sposób nowy kodeks odszedł od czysto cielesnego pojmowania małżeństwa.

\section{Słowa kluczowe}

płodność, pożycie małżeńskie, zgoda małżeńska, prawo do ciała (ius in corpus), ukierunkowanie ku potomstwu, zrodzenie i wychowanie dziecka

\section{Summary}

The procreative good (bonum prolis) in canonical marriage law. An attempt at synthesis

Following the directions of the Second Vatican Council, the current ecclesiastical legislation states in canon $1055 \$ 1$ that the institution of marriage is, in its very nature, apt for bonum prolis and bonum coniugum. This publication presents the characteristic change (evolution) that has been taking place in canon law in relation to the procreative good. This change is often described as a transition from the purely biological dimension into a personalistic one.

In the patristic thought and medieval canon studies, the marital intercourses were considered to be a remedy for lust (remedium concupiscentiae); however, through their aptness for new life, these acts became fully lawful (legal), and they were even a duty. This idea was adopted by the 1917 Code of Canon Law, which, in canon 1086 $\$ 2$, equated the procreative good with the right over the body (ius in corpus). As the 
analysis has shown, such a way of dealing with this question proved to be insufficient, as it did not consider a situation in which the spouses do not exclude the right to marriage acts itself, but they have an intention against the procreation of a child (e.g. by performing an abortion). The abovementioned lack or insufficiency was complemented by the new 1983 Code. According to its norms (regulations), the procreative good should be perceived in relation to a fruitful marriage act, in which the spouses mutually give themselves to each other and mutually accept their gifts of self. Thus, it is better to talk about the openness to life or potential maternity and paternity than about a right over the body, because in such an approach, having children is an affirmation of a mutual communion of persons. It is also worth mentioning that the canonical doctrine and the Vatican II documents univocally connect the procreative good with the duty of bringing up the children.

\section{Keywords}

fruitfulness, conjugal life, matrimonial consent, right over the body (ius in corpus), aptness for the generation of offspring, the procreation and upbringing of children 